\title{
Accounting, analysis and environmental audit as an imperative of the development of green economy in the state's economic security system
}

\author{
Karina Nazarova, Volodumyr Hotsuliak, Viktoriia Miniailo, Mariia Nezhyva, and Viktoriia Mysiuk \\ Kyiv National University of trade and economics, Financial analysis and audit department, 19 Kyoto Str., Kyiv, 02156, Ukraine
}

\begin{abstract}
The necessity of using accounting and auditing system is substantiated in the article, its main advantages are also defined. A model of accounting and audit support has been developed in the article, suitable for usage by forestry enterprises. In the system of rational forest management, accounting and auditing support of its management is of paramount importance, because it allows to monitor, document and verify for reliability all parties of financial and economic activities of forest users. In developing a system of accounting and audit of rational forest management, we are based on the fundamental categories of the classical scientific process, so its main elements are the object, subject, methods and subjects of research in the context of the relationship between the two components - accounting (by types) and economic and environmental audit of forest resources. Conducting an environmental audit in the forestry sector is complicated by the complexity of the audit object and the contradictory and multi-level relationships between its main elements. Internal audit is one of the few available and at the same time undervalued resources, the proper use of which can improve the efficiency of the enterprise and contribute to the orderliness of the management of economic processes.
\end{abstract}

\section{Introduction}

Information support of economic phenomena and processes today is a prerequisite for the development of effective management strategy, which is the basis for improving the efficiency of all economic activities without exception. In the context of growing demands for economic information, it is important to highlight and clearly differentiate the individual components of the information environment. For forestry, this issue is actualized due to the peculiarities of forest management, the length of the production cycle, which complicates the objective reflection of business operations in the formation and use of forest assets.

The aim of the study is based on providing theoretical approaches to the system of accounting and audit of rational forest management, which will improve the efficiency of forest management through the use of a set of institutional mechanisms of economic and environmental assessment, reflection and control of the use of forest biological assets, taking into account the dynamic balance of environmental, economic and economic balance, environment and society.

\section{Results and discussion}

The basis of rational forest management in the overall strategy of sustainable socio-economic and ecological development of the country focused on long-term perspective is the balancing of anthropogenic impact on forest biogeocenosis and ensuring parity between the growing needs of forest users and natural opportunities of the forest.

Global negative trends of recent decades are disturbance of the breed composition of forests, change of their age structure, thinning and weakening of biological stability of forest stands. Particularly acute and urgent are the problems of forests in Ukraine, where the forest cover is one of the lowest in Europe (Table 1).

Table 1. Forests in Europe.

\begin{tabular}{|l|c|c|c|}
\hline Country & $\begin{array}{c}\text { The total area of the } \\
\text { territory of the } \\
\text { country, thousand } \\
\text { hectares }\end{array}$ & $\begin{array}{c}\text { Area of } \\
\text { forested land, } \\
\text { thousand ha }\end{array}$ & $\begin{array}{c}\text { Forests, } \\
\text { \% }\end{array}$ \\
\hline Ukraine & 60370 & 9675 & 16,0 \\
\hline Sweden & 45218 & 27264 & 60,3 \\
\hline Finland & 33814 & 21883 & 64,7 \\
\hline France & 54919 & 15156 & 27,6 \\
\hline Spain & 50596 & 13509 & 26,7 \\
\hline Germany & 35702 & 10740 & 30,1 \\
\hline Italy & 30132 & 9857 & 32,7 \\
\hline Poland & 31268 & 8942 & 28,6 \\
\hline Norway & 32376 & 8710 & 26,9 \\
\hline Belarus & 20767 & 7850 & 37,8 \\
\hline
\end{tabular}

To bring the forest cover to the optimum level (about $20 \%$ ), it is necessary to accelerate the afforestation of all

\footnotetext{
* Corresponding author: artorix@ukr.net
} 
log cabins and forest areas not suitable for agriculture, steep slopes, level girder systems and deflated sands. Such measures will expand the country's forestry and environmental potential and conserve biodiversity. The main criteria for the cost-effectiveness of afforestation will be the reduction of erosion losses and the production of additional crop production [1]. It is worth noting that in Ukraine, as an agrarian state, there are no large reserves of areas that can be afforested, so it is not always possible to bring the actual forest cover level to the optimum due to objective circumstances.

The priority task of forestry enterprises is the restoration of forests (the process of formation of a new generation of forest under the tent of stands, log cabins, combustions and other areas where it has previously grown), which is carried out to achieve optimal forest cover, increase water protection, soil protection, other beneficial properties of the forest, improving the quality of plantations.
In the context of a critical level of anthropogenic load on natural resources, there is an objective need to rethink approaches to the management of natural assets in general and forest resources in particular, which should be based on the principles of sustainability, non-exhaustion and rationality. Green space is a sign of civilization, the cheapest and most effective biological means of environmental purification. Therefore, in view of the specific nature of the problem of global nature, it is important to summarize the concepts of "sustainable management", "sustainable forest management" and "rational forest management" to ensure uniformity in making effective decisions at all levels of management.

In the system of rational forest management, accounting and auditing support of its management is of paramount importance, because it allows to monitor, document and verify for reliability all parties of financial and economic activities of forest users (Fig. 1). Let us analyze each element of the accounting and auditing aspect of sustainable forest management.

\begin{tabular}{|c|c|}
\hline & Rational forest management \\
\hline $\begin{array}{l}\text { Organizational } \\
\text { aspect }\end{array}$ & $\begin{array}{l}\text { property right; constitutional guarantees; market conditions; international principles } \\
\text { of sustainable forest management: forest policy: }\end{array}$ \\
\hline $\begin{array}{l}\text { Accounting and } \\
\text { Auditing Aspect }\end{array}$ & $\begin{array}{l}\text { state accounting of forests; forest inventory; accounting for forest assets; electronic } \\
\text { timber accounting; internal and external audit of forest assets; }\end{array}$ \\
\hline $\begin{array}{l}\text { Forestry and taxation } \\
\text { aspect }\end{array}$ & $\begin{array}{l}\text { scientifically sound extraction of wood; restoration of plantations; conservation of } \\
\text { biodiversity; increasing the non-tree potential of the forest ecosystem; }\end{array}$ \\
\hline $\begin{array}{l}\text { Economic and } \\
\text { environmental aspect }\end{array}$ & $\begin{array}{l}\text { forest monitoring; environmental certification; objective valuation of forest assets; } \\
\text { self-sufficiency and self-financing of the sector; rational development of wood; non- } \\
\text { waste production; }\end{array}$ \\
\hline Psychological aspect & promoting the social benefits of the forest; culture of recreation and forest users; \\
\hline
\end{tabular}

Fig. 1. Forest management system.

Without a developed system of accounting and synthesis of information about the past, present and future events of the economic life of the enterprise it is impossible to make sound and prudent management decisions, which can lead to the risk of loss of control over financial and economic activities. Therefore, in order to increase the efficiency of activities, it is necessary to create an optimal organizational structure of management [2]. Accounting, as one of the tools to implement a management function, must be conducted in accordance with certain rules that maximize the effectiveness of management decisions made on their basis. The effect of proper accounting is reflected in timely preparation and submission of financial statements, preparation of other management information.

In our opinion, the contribution of audit to improving the reliability of accounting and analytical information is so significant that it is appropriate to distinguish a separate concept of "accounting and auditing" management of economic processes and phenomena. We believe that this definition is broader in nature because it covers a range of issues pertaining to the ongoing control over the formation and evaluation of accounting information. Thus, summarizing all of the above, we consider it appropriate to define accounting and auditing as a system of tools for collecting, assessing, processing, summarizing and accurately displaying accounting and analytical information for management purposes.

The current realities of forest management in the Ukrainian economy indicate that there is no clear strategy for accounting and auditing of forest management.

Accounting for forestry products does not ensure the exercise of control and management function, and the inconsistency of some aspects of it with international standards lead to obvious financial abuse in the industry. In view of increasing requirements for operational management of the assets of an enterprise, it is important to expand the information base, which will increase the efficiency and objectivity of tactical plans. In this regard, the rational forest management accounting and auditing system is intended to optimize and improve decision- 
making on sustainable forest management. It allows you to:

- generate complete and reliable information about forest users' economic activities and their property status;

- prevent negative results and reduce economic risks and identify internal reserves for ensuring the financial stability of the enterprise;

- control the availability, movement of property, manage the rational and purposeful use of material, labor and financial resources;

- make a scientifically sound system of indicators characterizing the results of the activity of the enterprise, its separate divisions and services;

comply with state discipline and lawfulness when dealing with economic issues.

Taking into account the specific features of forestry, the accounting and audit system also promotes:

- reliable assessment of plantation groups by age and breed composition, to further reflect them in the composition of non-current assets of forest users;

- regulation of expenses incurred by the enterprise during the turnover of the logs, with subsequent inclusion in the cost of finished products to calculate the objective cost of production;

- avoiding unacceptable losses of wood in the chain "ex-timber - ex-upper warehouse - ex-lower warehouse - consumer";

- control of the volume of forest plantations allocated for sanitary solid and selective felling;

- prompt reflection of all qualitative and quantitative changes that have occurred in the composition of forest assets as a result of realization of processes of forest users' economic activity.

In developing a system of accounting and audit of rational forest management, we are based on the fundamental categories of the classical scientific process, so its main elements are the object, subject, methods and subjects of research in the context of the relationship between the two components - accounting (by types) and economic and environmental audit (by type) of forest resources (Fig. 2).

As can be seen from the diagram, together with the accounting of forest resources, the simultaneous use of the main tools of auditing control of forest assets is envisaged. Given the exceptional importance of forest ecosystems in quaternary processes, forest audits should be conducted not based on the traditional economic criterion of efficiency but on the criterion of economic, environmental and social efficiency of forestry. That is why we propose to introduce into scientific circulation the concept of economic and environmental audit. A distinctive feature of the economic and environmental audit of the forest sector is the establishment of environmental validity and legality of forestry and reforestation.

In the context of material production, accompanied by increasing pressure on the environment and excessive depletion of natural resources, it is important to provide the public, state institutions, economic entities with reliable, timely and objective information on the state of natural ecosystems, measures taken to green the production processes and opportunities to prevent the spread of corruption tendencies in economic activities of environmental users.

Forest management features make this issue more relevant in the absence of a transparent and impartial systematic control over operations that affect the environmental status of forest biogeocenosis. This task is facilitated by the implementation of forestry practices of external and internal economic and environmental audits, which, as a means of identifying doubtful financial and economic transactions that can serve as a source of shadow income and unjustified environmental risks, occupy an important place in the economy and the system of economics farms. In addition to audits, auditing is also an effective way of controlling the targeted use of budget funds in forestry enterprises. In the separate concept of internal economic and environmental audit of forestry by scientists has not yet been identified, so we consider it necessary to submit our own interpretation of this definition, which defines internal economic and environmental audit as a component of the internal control system, which is an independent, comprehensive, documented assessment of the activities of forest users subject to compliance with the requirements of the applicable economic and environmental law in order to provide practical recommendations for improving the effectiveness of management decisions to prevent Nude risks of error, fraud, waste, etc., and promotes rational forestry.

Conducting an environmental audit in the forestry sector is complicated by the complexity of the audit object and the contradictory and multi-level relationships between its main elements. In addition, the downward trend in effective demand for audit services requires forest sector enterprises to organize in-house control of forest biological assets through the introduction of internal economic and environmental audits as an effective tool in improving the efficiency of management of forest management.

Internal audit is one of the few available and at the same time undervalued resources, the proper use of which can improve the efficiency of the enterprise and contribute to the orderliness of the management of economic processes. The main objective of an environmental audit is to optimize the financial and economic activity of the enterprise not by detecting irregularities and mistakes for further organizing and punishing the perpetrators, but by finding and assessing risks, weaknesses in the work of the structural unit or enterprise and providing practical recommendations for improving the efficiency of adoption management decisions. Given that internal audit provides information on all aspects of the enterprise's activities and tools for generalizing and analyzing data, interacting with it enhances the effectiveness of the decisions made. It provides expert science-based assessment of business operations and processes.

The peculiarity of internal economic and environmental audit in forestry enterprises (as opposed to audits or external audit) is its perspective orientation, that is, the design and analysis of future events that may adversely affect the environmental condition of forest assets and prevent the threat of loss control and loss 
control. ecological validity of carrying out separate production and economic processes in state forestry.

The prerequisite for the use of internal economic and environmental audit in forestry enterprises is the development of a legal framework, control parameters, standards, etc. in coordination and compliance with the geographical (natural and climatic) features of forestry.

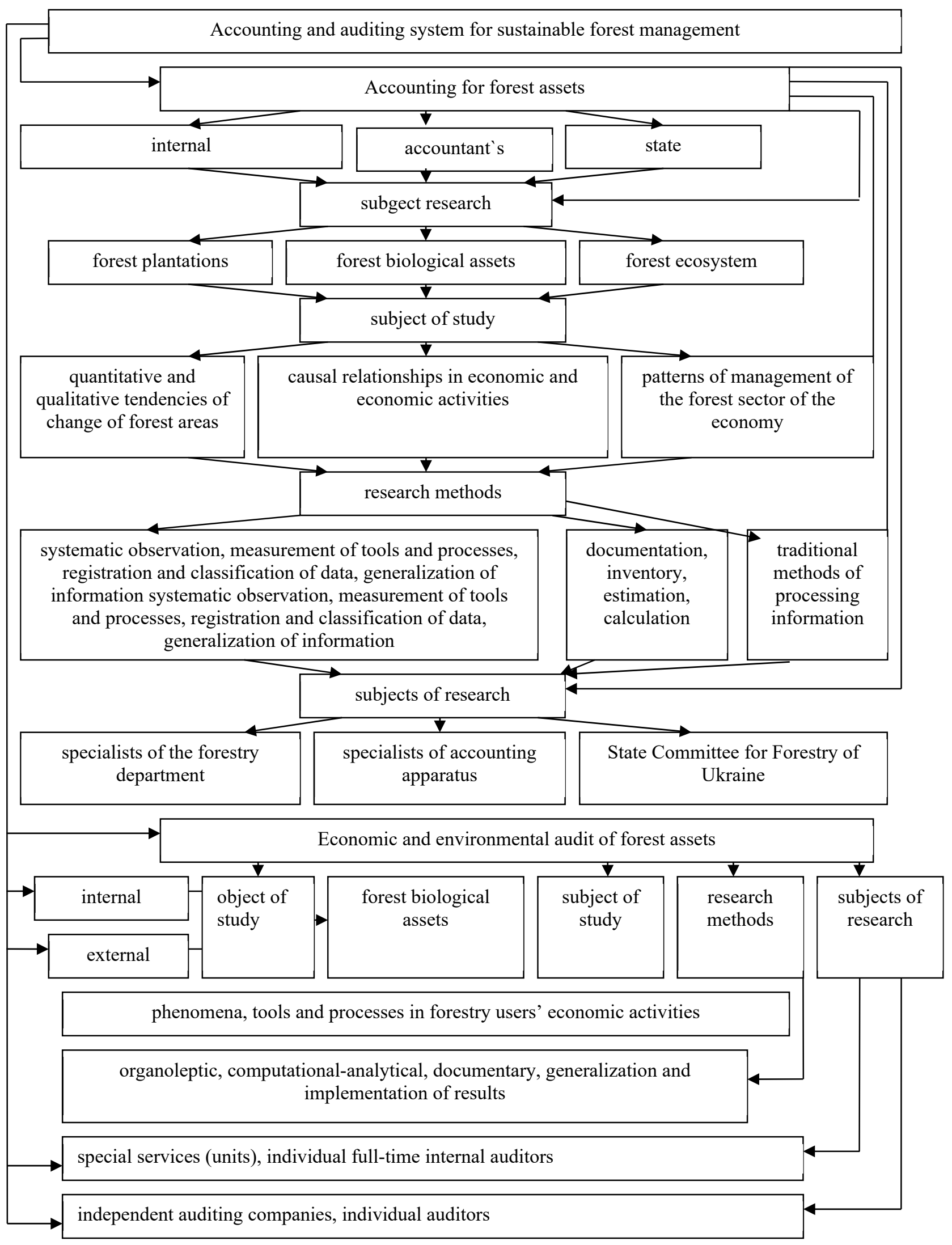

Fig. 2. The system of accounting and audit support of rational forest management. 
The organization and conduct of internal economic and environmental audits must comply with certain principles, among which the following are the main ones:

- the obligation to take into account the requirements of environmental safety and sustainable development of the territory;

- accounting and assessment of natural and socioeconomic features of the territory, current and prospective state of the environment;

- the accuracy and completeness of the information used for the audit;

- scientific validity, objectivity and openness of audit results.

Internal audit aims at internal control over the organization and functioning of accounting systems - not only accounting, management, operational, but also environmental, which is based on the systematic use of economic and environmental information on the status, formation and use of audit objects in accordance with to the requirements of environmental legislation and conceptual principles of sustainable forest management. Control over the organization of the accounting system is the implementation of part of the management functions of the management of the company, so the performers of internal economic and environmental audit should be impartial and objective in their analytical actions and provide a complete and permanent assessment of financial and economic processes from the standpoint of economic, environmental and social feasibility.

Internal economic and environmental audit in forestry performs a number of tasks, the main of which are:

a) collecting reliable information on environmental aspects of forestry production activities;

b) establishing the compliance of forest ecosystems with the requirements of the legislation on environmental protection and other criteria;

c) evaluation of the results of the activities of forest users in the context of environmental impact;

d) assessment of the effectiveness, timeliness, completeness and validity of the measures taken to minimize the negative impact on the forest ecosystem and the environment;

e) preparation of recommendations on optimization of the use of forest resources and prevention of environmental risks in the activities of forestry enterprises.

Internal audit, as a management tool for forest management, should be considered on a systematic approach. Based on the systematic approach to management, we have developed a procedure for implementing accounting and control functions of management (through internal audit), in which all stages, depending on the performed operations, are divided into separate blocks: planning, organization, execution, control (Fig. 3).

The general model of internal economic and ecological audit of the enterprises of the forestry sector looks like this (Fig. 4).

In the audit process, the priority is to verify:

- compliance of primary forest accounting data with the state forest inventory;

- the availability of legal support for permanent use of forests, which is certified by a state act on the right of permanent use of land;

- compliance of the actual sizes of the plots allocated for special use with the standards of the calculated logging;

- the proportionality of the volume of actual removal of timber with the norms (limits) of harvesting timber from logging;

- observance of the proportions recommended by the state forestry organizations regarding the yield of timber by the breed composition of plantations (coniferous, softwood, hardwood) and especially valuable breeds;

- completeness of development of logging fund in accordance with assortment tables;

- the validity of the logging waste and primary wood processing and the completeness of their use in economic activity;

- the lawfulness of permits for the special use of forest resources in the allocated forest area (logging tickets, warrants, forest tickets);

- compliance of the actual volumes of timber extraction with the volumes specified in the permits;

- the size of defects (at certification of places of harvesting) in development of the logging fund;

- compliance with the timing of collection of forest resources.

Systematic operations are also subject to operations with recovered wood. In this context, it is important to check:

- conformity of the quantitative and qualitative (breed and assortment) composition of the wood indicated in logging tickets to the actual sizes on logs, upper and lower storage depots;

- the reliability of the cost estimate of the forest products received and the validity of its initial posting in the accounting of state forestry;

- comparability of fuel standards and actual volumes of timber released to employees;

- volumes of timber (including export deliveries) broken down by breed and assortment composition during the reporting period (quantitative and cost indicators are checked for detection of discrepancies between the data of primary documents and actual residues of timber production in warehouses);

- the accuracy of the costs incurred by the enterprise in harvesting the timber;

- the lawfulness of the distribution and attribution of costs for the production cost of sales;

- accounting for operations related to the procurement and sale of secondary forest materials and by-products of forestry (including specially created for this plantation), which are carried out for the needs of production and commercial activities in the order of special use and are carried out for payment on the basis of the forest ticket within the allotted areas of the forest fund;

- objectivity in accounting for the costs of forestry services.

Summarizing the above, it should be noted that the implementation of internal economic and environmental audit of forestry enterprises is a labor-intensive process, the results of which can significantly improve the effectiveness of the decisions taken on the management of 
rational forest management and prevent unjustified economic and environmental risks in the future. Therefore, the search for opportunities and the development of practical recommendations for improving environmental safety, biodiversity conservation and sustainable forest management should be based on a systematic study:

- ways of improving industrial environmental control;

- possible steps to improve the forest ecosystem protection management system;

- the most effective available technologies for accounting of forest assets, advanced rational development of forest resources and mechanisms for timely and complete reproduction of forest plantations.

This paved the way for new challenges - to evaluate, through internal audit, the state of forestry and the main opportunities for improving its economic and environmental performance.

The optimal and efficient use of waste as a valuable raw material for processing minimizes the loss of forest products and increases the economic and environmental impact of sustainable forest management. The main possibilities of waste recycling, to increase the economic effect are: production of technological chips, tare boards; manufacture of building structures (eg., arbolite, xylolite, parquetite); production of structural fiber materials (eg., fibrex); bio conservation; production of fuel briquettes (briquettes from wood waste and bark do not actually contain sulfur, so in the products of their combustion there is no sulfur gas, and the content of carbon monoxide is minimal); production of fuel wood pellets.

A systematic approach in the implementation of accounting and control functions of management

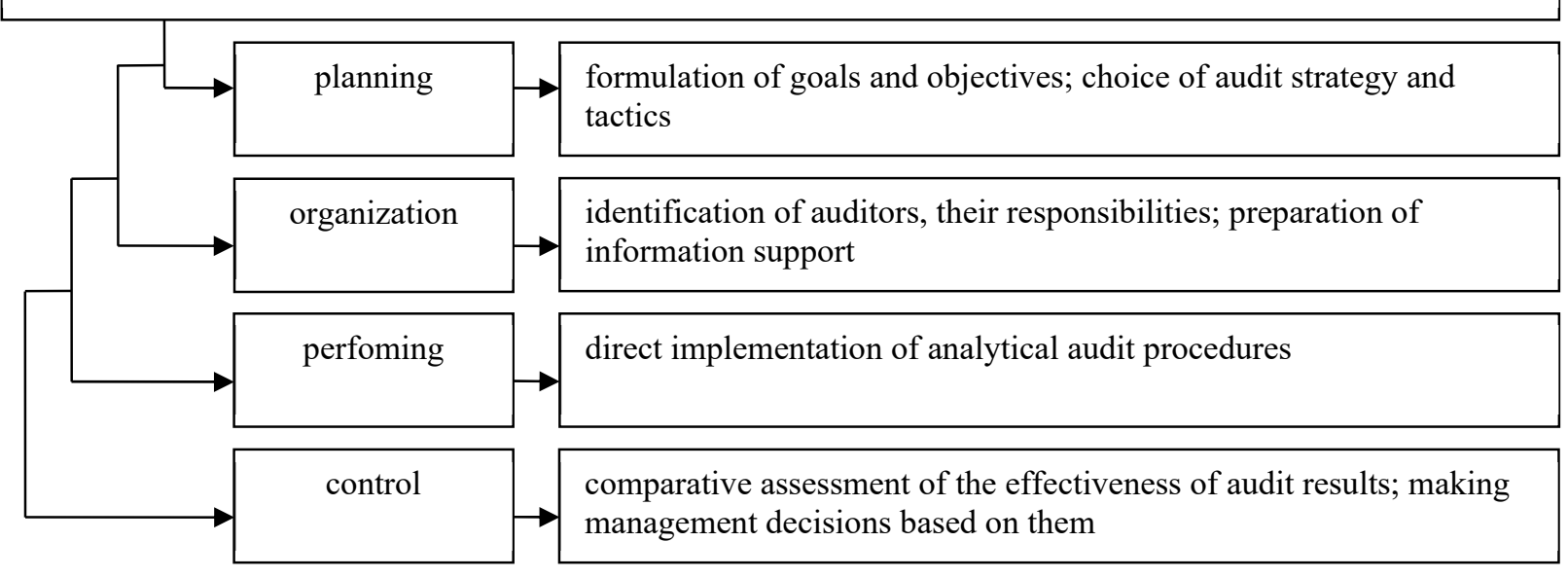

Fig. 3. The algorithm of implementation of accounting and control function of management.

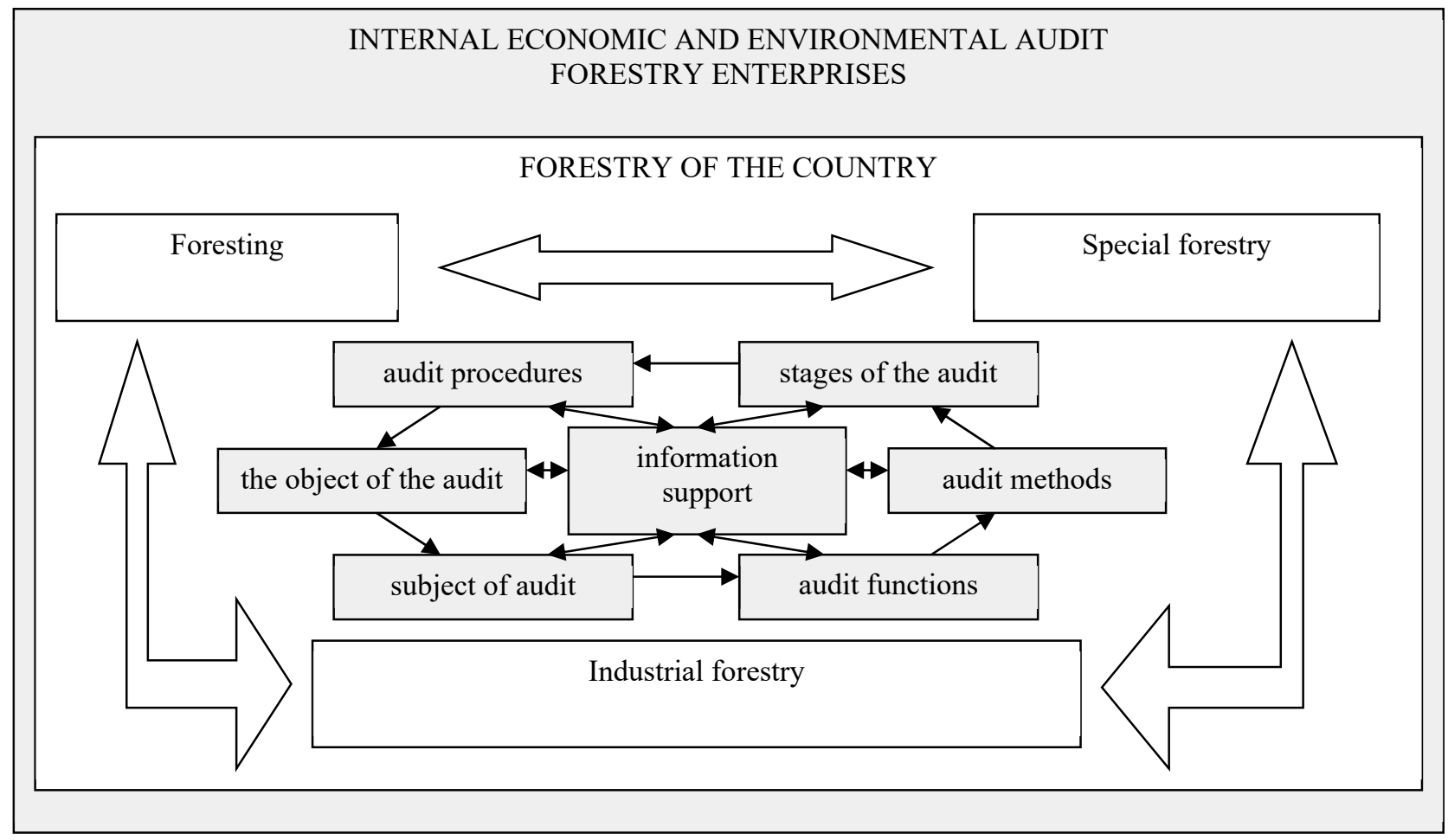

Fig. 4. Model of internal economic and environmental audit of forestry enterprises. 
To increase environmental efficiency, the experience of grinding forest waste to a small fraction, followed by scattering over the area of the forest area, is positive, which allows:

- to provide optimal conditions for seed germination (and therefore promotes the natural restoration of forest plantations);

- to control the phytosanitary state of forests and prevent the occurrence of pests (due to the balance of the mineral nutrition of plantations).

\section{Conclusions}

Todays World green economy trend is not only about nature management in real day to day life, it is also about information support and assurance of such managmet, that is based on nature managing accounting procedures. It assures base for green economy development planning and control of it's performing throught the permanent analisis of changes and its impact on future green economy parametrs. Green economy needs management approachs of permanent optimization that is based on effective and trustworthy data provided by cvalifide persone - auditor. Green economy audit, that is based on accounting and analitic data provides directions of srtategyc effective segment developmet to overcome World ecological problems. Novedays there is only one worldknown instrument that provides reall independent analisis and recommendations of different process optimization - audit. Green economy also is under it's sphere of influence and neeed to be considered as "must".

Thus, balancing the cost structure, strengthening the internal control over the processes of restoration and use of forest biological assets, will contribute to the deepening of rational forest exploitation, based on environmentally sound and cost-effective principles. The practical value of economic and environmental audit under these conditions is to improve the mechanism of making effective management decisions to increase the resource potential of forestry, as a necessary prerequisite for ensuring sustainable forest management.

\section{References}

1. S.A. Gensiruk, Lisy Ukrayiny (Nauk. tov. im. Shevchenka, Ukr. derzh. lisotexnichnyj universytet, 2002)

2. M.S. Pushkar, M.T. Shhyrba, Teoriya i praktyka formuvannya oblikovoyi polityky (2010)

3. Enviromental audit committee (2019), https://committees.parliament.uk/committee/62/envi ronmental-audit-committee. Accessed 28 Mar 2020 